\title{
Desmopressin Stimulation Test for Diagnosis of ACTH-Dependent Cushing's Syndrome $\#$
}

\author{
YoKo SAKAI, NobUo HORIBA, FUMIKo TOZAWA*, KEN SAKAI, \\ Akio KUWAYAMA**, Hiroshi DEMURA*, AND TOSHIHIRo SUDA \\ Third Division, Department of Medicine, Hirosaki University School of Medicine, Hirosaki 036, \\ *Department of Medicine, Institute of Clinical Endocrinology, Tokyo Women's Medical College, Tokyo 162, and \\ **Department of Neurosurgery, Nagoya National Hospital, Nagoya 460, Japan
}

\begin{abstract}
We evaluated the usefulness of a desmopressin (DDAVP) test in the diagnosis of ACTHdependent Cushing's syndrome. After an intravenous injection of $5 \mu \mathrm{g}$ DDAVP, plasma ACTH levels increased to more than $200 \%$ of the basal levels in 10 of 10 patients with Cushing's disease, but remained less than $150 \%$ in all of 11 normal subjects, 3 patients with Addison's disease, 5 cases of Cushing's disease in remission, and 3 patients with ectopic ACTH syndrome. Peak levels of plasma cortisol after the DDAVP stimulation were $159 \pm 14 \%$ in the patients with Cushing's disease, and less than $150 \%$ of the basal levels in the other 5 groups. We also found a case of Cushing's disease with periodicity which responded to DDAVP only in the active stage. In vitro studies revealed that DDAVP directly stimulates $\mathrm{ACTH}$ release from corticotropic adenoma cells through V1b but not V2 vasopressin receptors. In conclusion, the DDAVP stimulation test, i.e., determination of plasma ACTH levels after $5 \mu \mathrm{g}$ DDAVP injection, seems useful for discriminating Cushing's disease from normality, and may serve to facilitate the differentiation between Cushing's disease and ectopic ACTH syndrome.
\end{abstract}

Key words: Desmopressin, Vasopressin receptors, ACTH, Diagnosis of Cushing's syndrome, Cyclic Cushing's disease

(Endocrine Journal 44: 687-695, 1997)

CUSHING'S syndrome can be divided into 2 groups, ACTH-dependent and ACTH-independent. The ACTH-independent types of Cushing's syndrome are caused by autonomous cortisol secretion from adrenal lesions including adenoma, carcinoma, primary micronodular dysplasia, and ACTH-independent macronodular hyperplasia [13]. Diagnosis of ACTH-independent Cushing's syndrome has become easier with advances in

Received: January 20, 1997

Accepted: May 28, 1997

Correspondence to: Dr. Yoko SAKAI, Third Division, Department of Medicine, Hirosaki Univresity School of Medicine, 5 Zaifu-cho, Hirosaki 036, Japan

\#Part of this study was presented at the 76th Annual Meeting of the Endocrine Society, June 15-18, 1994, at Anaheim, CA. adrenal computed tomographic (CT) scanning and ACTH assay that demonstrates suppressed plasma ACTH levels in this syndrome. However, 2 major obstacles to the diagnosis of ACTH-dependent types of Cushing's syndrome (which include Cushing's disease and ectopic ACTH/CRH syndrome) remain. First, it is sometimes difficult to discriminate this type of Cushing's syndrome from normal or other non-Cushing conditions. Especially in Cushing's disease, morning plasma levels of both ACTH and cortisol are often within the normal ranges, and normal subjects under stressful conditions sometimes show elevated levels of these hormones. Thus, plasma cortisol resistance to the dexamethasone suppression test (DST) [4] should be proved before diagnosing Cushing's disease. With some cases of particular disorders such as depression or alcoholism, however, plasma 
cortisol also exhibits resistance to the DST. The second problem is differentiating between Cushing's disease and ectopic ACTH/CRH syndrome. Although the $\mathrm{CRH}$ test [5] and highdose DST, sometimes together with metyrapone test, are useful routine examinations for the differential diagnosis [6], some cases of ectopic $\mathrm{ACTH} / \mathrm{CRH}$ syndrome respond to these tests much like typical cases of Cushing's disease [6, 7]. In addition, image diagnosis may fail to demonstrate a tumor causing ectopic ACTH syndrome (occult ectopic ACTH syndrome). Petrosal sinus catheter studies appear to approach $100 \%$ diagnostic accuracy excepting ectopic $\mathrm{CRH}$ production, but are expensive in terms of both time and resources, and require specialist expertise [8]. Somatostatin radioanalog scintigraphy is a potentially useful and noninvasive procedure for the localization of bronchial carcinoid tumors in ectopic ACTH syndrome [9], but has not yet come into practical use.

Arginine vasopressin (AVP) is a neuropeptide with various physiologic functions including regulation of water reabsorption and vasoconstriction. It is also a physiological stimulator of pituitary ACTH release and is thought to act synergistically with CRH. AVP exerts these diverse effects through at least 3 distinct subtypes of $G$ protein-coupled receptors termed V1a, V1b and V2 vasopressin receptors. The V2 receptor mediates water reabsorption via activation of adenylate cyclase in the kidney, and the V1a receptor stimulates vascular smooth muscle contraction via induction of phosphatidylinositol (PI) turnover. The adenohypophysial receptor involved in VP-induced ACTH release is also linked to PI turnover [10] but is pharmacologically distinguished from V1a [11] as V1b. These three receptor subtypes have been cloned [12-14].

Recently, Malerbi et al. [15] reported plasma cortisol responses to intravenous injection of 5 or $10 \mu \mathrm{g}$ of desmopressin (1-deamino [4-valine, 8-Darginine] vasopressin, DDAVP), a selective V2 receptor agonist [16], in 15 of 16 patients with Cushing's disease, 2 of 15 normal subjects, and none of 9 patients with Cushing's syndrome (8 with adrenal dependence and one with ectopic ACTH production). They concluded that the DDAVP test, like the $\mathrm{CRH}$ test, may prove useful in the differential diagnosis of Cushing's syndrome.

In the present study, we extended the study of
Malerbi et al. [15] by measuring plasma ACTH levels during the DDAVP test, adding three cases with ectopic ACTH syndrome and assessing the mechanisms of the DDAVP action by in vitro studies. Our observations indicated that measurement of plasma ACTH levels after $5 \mu \mathrm{g}$ DDAVP injection could be done with higher sensitivity and higher specificity, facilitating the differentiation of Cushing's disease from normality and ectopic ACTH syndrome.

\section{Subjects and Methods}

\section{Experimental subjects}

The DDAVP test was performed on 6 groups of test subjects; 11 normal healthy volunteers (6 women and 5 men) aged 25 to $51 \mathrm{yr}, 10$ patients with Cushing's disease aged 16 to $59 \mathrm{yr}, 3$ patients with ectopic ACTH syndrome aged 41 to $46 \mathrm{yr}, 5$ patients with Cushing's disease in remission, and 3 patients with Addison's disease before starting glucocorticoid replacement.

The diagnosis of Cushing's disease was histologically confirmed in all cases after transsphenoidal surgery. Remission of Cushing's disease after the operation was determined by low plasma cortisol and ACTH levels with nonresponse to CRH in the early post-operative period, and complete response to the DST in the recovery period of the pituitary-adrenal axis. In 3 patients grouped into ectopic ACTH syndrome, clinical signs, hypercortisolemia resistant to the high-dose DST, and high plasma ACTH levels indicated ACTH-dependent Cushing's syndrome. But repeated pituitary magnetic resonance (MR) imaging did not demonstrate pituitary tumors, petrosal sinus sampling did not reveal significant gradient of ACTH level, and transsphenoidal surgery with $90 \%$ survey of the pituitary could not find a tumor. From these findings, they were diagnosed as occult ectopic syndrome. One patient then received total hypophysectomy without improvement of Cushingnoid symptoms, and a lung tumor became evident later.

We also performed the human CRH (hCRH) test on 9 of the 10 patients with Cushing's disease and on 18 normal subjects, and the lysine-8-vasopressin (LVP) test on 4 of the patients with Cushing's disease and 16 normal subjects. 
The study subjects received the tests after giving informed consent.

\section{In vivo examinations}

During the DDAVP test, the study subjects remained supine and fasting from the previous evening. A needle catheter was kept in the forearm of each subject from $30 \mathrm{~min}$ before treatment. Sterilized DDAVP (Kyowa Hakko Co., Tokyo, Japan) was injected intravenously at a dose of $5 \mu \mathrm{g}$ at $0800 \mathrm{~h}$. Blood samples were drawn at $0,15,30$, 60 and $90 \mathrm{~min}$ after the treatment and were placed in ice-cold heparinized and EDTA tubes for measuring cortisol and ACTH, respectively. Each sample was immediately centrifuged at $4{ }^{\circ} \mathrm{C}$ and the plasma was stored at $-20^{\circ} \mathrm{C}$ until assayed. Testing with hCRH or LVP was performed in the same way as with DDAVP after intravenous injection of $100 \mu \mathrm{g}$ synthetic hCRH (Peptide Institute Inc., Osaka, Japan) or intramuscular administration of 10 I.U. LVP (Sandoz, Basel, Switzerland), respectively.

\section{In vitro studies}

Pituitary corticotropic adenoma tissue obtained by transsphenoidal surgery from three patients with Cushing's disease was minced and incubated in sterile HEPES-buffered saline containing $0.4 \%$ collagenase (Sigma Chemical Co., St. Louis, MO), $0.04 \%$ dispase (Sanko Pure Chemical, Tokyo, Japan), $0.002 \%$ DNase (Sigma Chemical Co., St. Louis, MO), and $2 \%$ bovine serum albumin (BSA) for $20 \mathrm{~min}$ at $37^{\circ} \mathrm{C}$. The tissue was dispersed by pipetting, washed twice, then resuspended with HEPES-buffered Dulbecco's modified Eagle's medium (DMEM) containing 10\% fetal calf serum (FCS). Aliquots of $2 \times 10^{5}$ cells were placed in 12well (22.1 mm diameter) culture clusters (Costar, Cambridge, MA) and incubated at $37{ }^{\circ} \mathrm{C}$ in humidified $95 \%$ air- $5 \% \mathrm{CO}_{2}$. After 3 to 4 days of culture, the cells were washed with serum-free HEPES-buffered DMEM containing 0.2\% BSA, then incubated with the serum-free medium containing $100 \mathrm{nmol} / \mathrm{L}$ of DDAVP, $10 \mathrm{nmol} / \mathrm{L}$ of CRH, or 100 $\mathrm{nmol} / \mathrm{L}$ of AVP (Peptide Institute Inc.) for $3 \mathrm{~h}$. At the end of incubation, the medium was saved for ACTH RIA.

To measure cAMP accumulation, corticotropic adenoma cells from 2 of the 3 cases were treated as previously described [17].

\section{Hormonal analysis}

Plasma ACTH levels were determined by immunoradiometric assay, as previously reported [18]. Plasma cortisol levels were measured by RIA using commercially available kits (Amersham International plc., Buckinghamshire, UK). Intraand interassay variances were less than $5.7 \%$ and $8.9 \%$, respectively, and sensitivity was $16 \mathrm{nmol} / \mathrm{L}$ [3].

$\mathrm{ACTH}$ in the incubation medium was measured by RIA based on the reported method [19] with a new strain of antiserum raised against ACTH-(124), and ${ }^{125}$ I-labeled ACTH-(1-39) as a tracer. The antiserum was used at a final dilution of 1:150,000. The sensitivity of this assay was $0.66 \mathrm{pmol} / \mathrm{L}$. The intra- and interassay variances were less than $5 \%$ and $10 \%$, respectively.

Total cAMP levels in culture medium and cytoplasm were determined with RIA kits from Eiken ICL (Tokyo, Japan). The sensitivity of this assay was $0.5 \mathrm{nmol} / \mathrm{L}$. Intra- and Interassay coefficients of variation with this assay were both less than $20 \%$.

\section{RNA extraction and northern blot analysis}

Total RNA was extracted from a corticotropic adenoma by the acid guanidinium-phenolchloroform method [20], then $\mathrm{V} 2$ and $\mathrm{V} 1 \mathrm{~b}$ receptor mRNA levels were determined by Northern blot analysis as previously described [7]. In brief, the RNA samples $(0.5-1 \mu \mathrm{g})$ were denatured with 1 $\mathrm{mol} / \mathrm{L}$ of glyoxal and $50 \%$ dimethylsulfoxide and electrophoresed on a $1.4 \%$ agarose gel in $10 \mathrm{mmol} /$ L sodium phosphate buffer ( $\mathrm{pH} 7.0)$. After electrophoresis, the RNA was transferred to a filter (Gene Screen; DuPont/NEN, Boston, MA) and fixed under UV with a UV cross-linker (UV Stratalinker 1800, Stratagene, LA Jolla, CA). The filter was prehybridized for $6 \mathrm{~h}$ and then hybridized with $1 \times 10^{7} \mathrm{cpm} / 10 \mathrm{ml}$ radioactive cRNA probe. Hybridization was performed at 60 ${ }^{\circ} \mathrm{C}$ for $48 \mathrm{~h}$ in a hybridization buffer of the following composition: $6 \times$ SSC $(1 \times$ SSC $=150$ $\mathrm{mmol} / \mathrm{L}$ of sodium chloride and $15 \mathrm{mmol} / \mathrm{L}$ of sodium citrate, $\mathrm{pH} 7.4$ ), $50 \%$ formamide, $2 \%$ SDS, and $100 \mu \mathrm{g} / \mathrm{ml}$ of denatured sheared salmon sperm DNA. At the end of incubation, the filter was 
washed twice at room temperature in $2 \times$ SSC with $1 \%$ SDS, and several times at $60{ }^{\circ} \mathrm{C}$ in $0.1 \times$ SSC with $1 \%$ SDS. After washing, the filters were exposed to Kodak XAR-5 x-ray film (Eastman Kodak, Tokyo, Japan). Normal human kidney tissue dissected with renal cellular carcinoma was also used as a positive control for V2 receptor detection. Radioactive cRNA probes used in the Northern hybridization were generated with ${ }^{32} \mathrm{P}-$ CTP (New England Nuclear Research Products, Boston, MA) by SP6 promoter on the PCRII vector (Invitrogen, San Diego, CA) in which human V2 or $\mathrm{V} 1 \mathrm{~b}$ receptor cDNA had been cloned. A human V2 receptor gene fragment was amplified by PCR from genomic DNA and cloned into the PCRII vector. Genomic DNA was prepared from white blood cells of a healthy volunteer by the standard technique. PCR primers (Nihon Bioservice, Tsukuba, Japan) flanking the coding region of the V2 receptor were synthesized in accordance with the reported sequence [13]. The generous gift of a human V1b receptor cDNA clone [14] from the Yamanouchi Institute for Drug Discovery Research (Tsukuba, Japan) was subcloned into the PCRII vector. A cDNA encoding human $\mathrm{V} 2$ receptor was also kindly provided by Dr. Y. Iwasaki (Nagoya Univ., Nagoya, Japan).

\section{Statistical analysis}

Data were statistically evaluated by one-way analysis of variance followed by Duncan's multiple range test, nonparametric Mann and Whitney test, or two-way analysis of variance after evaluation of uniformity of the variances by Bartlett's test.

\section{Results}

\section{In vivo examinations}

As shown in Fig. 1, patients with Cushing's disease exclusively showed plasma ACTH response to intravenous injection of $5 \mu \mathrm{g}$ of DDAVP. The plasma ACTH levels in 10 of 10 patients with Cushing's disease increased to more than 200\% (295 \pm 53 ) (Mean $\pm S D$ ) of the basal levels after DDAVP administration, whereas the plasma ACTH levels remained less than $150 \%$ of the basal levels in all of 11 normal subjects $(100 \pm 6), 3$ patients with
Addison's disease (110 \pm 7$), 5$ cases of Cushing's disease in remission (109 \pm 12$)$ and 3 patients with ectopic ACTH syndrome (123 \pm 11$)$.

The peak levels of plasma cortisol after DDAVP stimulation were $159 \pm 15 \%$ of the basal levels in patients with Cushing's disease, and less than $150 \%$ of the basal levels in the other five groups.

According to the criterion adopted by Malerbi et al. [15] responders to the DDAVP test, whose plasma cortisol levels exceeded the basal levels plus 4 times the intra-assay variances of RIA after the DDAVP administration, included 6 of 10 patients with Cushing's disease, none of 11 normal subjects, and 2 of 5 patients with Cushing's disease in remission; false-negative and false-positive response rates were $18.2 \%$ and $10 \%$, respectively (Table 1). If relative changes in plasma ACTH concentrations are used as the diagnostic index, responders (whose plasma ACTH exceeded 1.5 times the basal levels) included 10 of 10 patients with Cushing's disease, and none of 11 normal subjects; there was no false-negative or falsepositive response.

Figure 2 compares plasma ACTH responses to the CRH, LVP and DDAVP tests. Normal subjects showed almost the same plasma ACTH responses to CRH and LVP. Three patients with Cushing's disease showed a weaker, and one a greater response to the LVP test than to the CRH test, but plasma ACTH responded to the DDAVP test only in the patients with Cushing's disease.

In a case of Cushing's disease exhibiting periodicity of clinical manifestation, the CRH test and the DDAVP test were performed at both active and trough stages. As is clear from Fig. 3, plasma ACTH showed similar responses to CRH in both stages, but responded to DDAVP only in the active stage.

All 33 cases were carefully observed for adverse effects during and after the DDAVP test. Changes in clinical signs and symptoms were found in 7 cases $(21 \%)$. The most common sign was flushing with facial suffusion and a burning sensation, seen in 4 cases. The symptoms appeared within $5 \mathrm{~min}$ after the DDAVP administration and disappeared within $15 \mathrm{~min}$ after their onset. Other side effects observed were chest discomfort in 1 case and decrease in urine volume in 2 cases, but both were slight, with the former disappearing in a minute and the latter in hours without any treatment. 


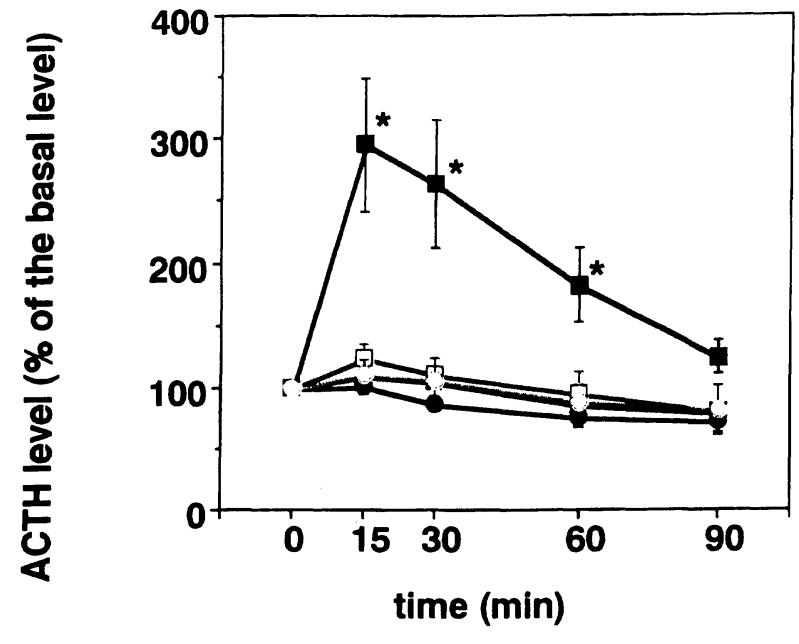

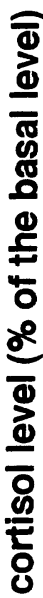

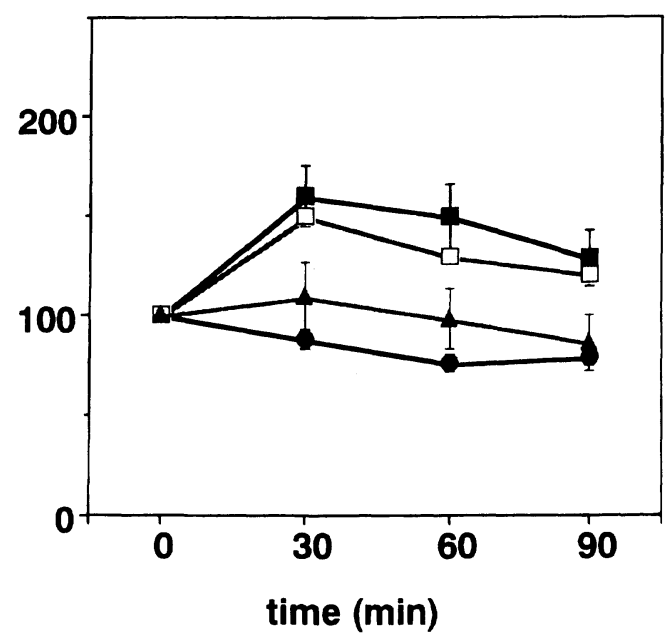

Fig. 1. Plasma ACTH (upper) and cortisol (lower) responses to the DDAVP stimulation test. Five $\mu \mathrm{g}$ of DDAVP was administered by an intravenous bolus injection. Solid circle: normal subjects $(n=11)$; closed square: patients with Cushing's disease $(n=10)$; open square: patients with Cushing's disease in remission $(n=5)$; closed triangle: patients with ectopic ACTH syndrome $(n=3)$; open circle: patients with Addison's disease before starting glucocorticoid replacement $(n=3)$. Values are the mean \pm SEM. *: $P<0.05$ vs. normal subjects.

\section{In vitro studies (Table 2)}

As shown in Table 2, ACTH levels in the incubation media were elevated with $100 \mathrm{nmol} / \mathrm{L}$ of DDAVP or AVP as well as with $10 \mathrm{nmol} / \mathrm{L}$ of
Table 1. Comparison of two criteria for the differentiation of Cushing's disease from normality

\begin{tabular}{lcc}
\hline & false-positive (\%) & false-negative (\%) \\
\hline M1 $^{\text {a) }}$ & 6.25 & 8.33 \\
M2 $^{\text {b) }}$ & 10.0 & 18.2 \\
Ours $^{\text {c) }}$ & 0 & 0 \\
\hline
\end{tabular}

"False-positive" refers to the percentage of responders to the DDAVP test among normal subjects. "False-negative" refers to percentage of non-responders to the DDAVP test among patients with Cushing's disease. ${ }^{\text {a) }} \mathrm{M} 1$ : data from the report of Malerbi et al. [15]. b) M2: results of the present study analyzed by the criterion of Malerbi $e t$ al. [15]. c) Ours: results of the present study analyzed by our criterion, which defines responders to DDAVP as those who show peak plasma ACTH levels exceeding $150 \%$ of the basal level.

CRH. On the other hand, cAMP accumulation increased to 3 to 4 times the control levels by the treatment with $\mathrm{CRH}$, but did not change with AVP or DDAVP.

\section{Northern blot analysis (Fig. 4)}

Northern blot analysis with the human V2 receptor probe revealed a single hybridization band of $1.8 \mathrm{~kb}$ in the kidney, but none was detected in corticotropic adenoma cells. On the other hand, $4.8 \mathrm{~kb} \mathrm{V1b}$ receptor mRNA was detected in the tumor cells, but not in the kidney.

\section{Discussion}

Cushing's syndrome is a constellation of clinical signs and symptoms resulting from chronic glucocorticoid excess. The diagnostic laboratory approach for Cushing's syndrome is the first, to confirm the existence of Cushing's syndrome, and the second, to determine its cause. Various authors have compared the value of one test with another for demonstrating and defining the cause of Cushing's syndrome. Discrimination of Cushing's disease from normal subjects or ectopic ACTH/ $\mathrm{CRH}$ syndrome remains particularly difficult.

Intravenous administration of $5 \mu \mathrm{g}$ DDAVP caused a rapid increase in plasma ACTH levels in patients with Cushing's disease: the plasma ACTH concentrations rose significantly and peaked at 15 min after the injection in most cases. The prompt 

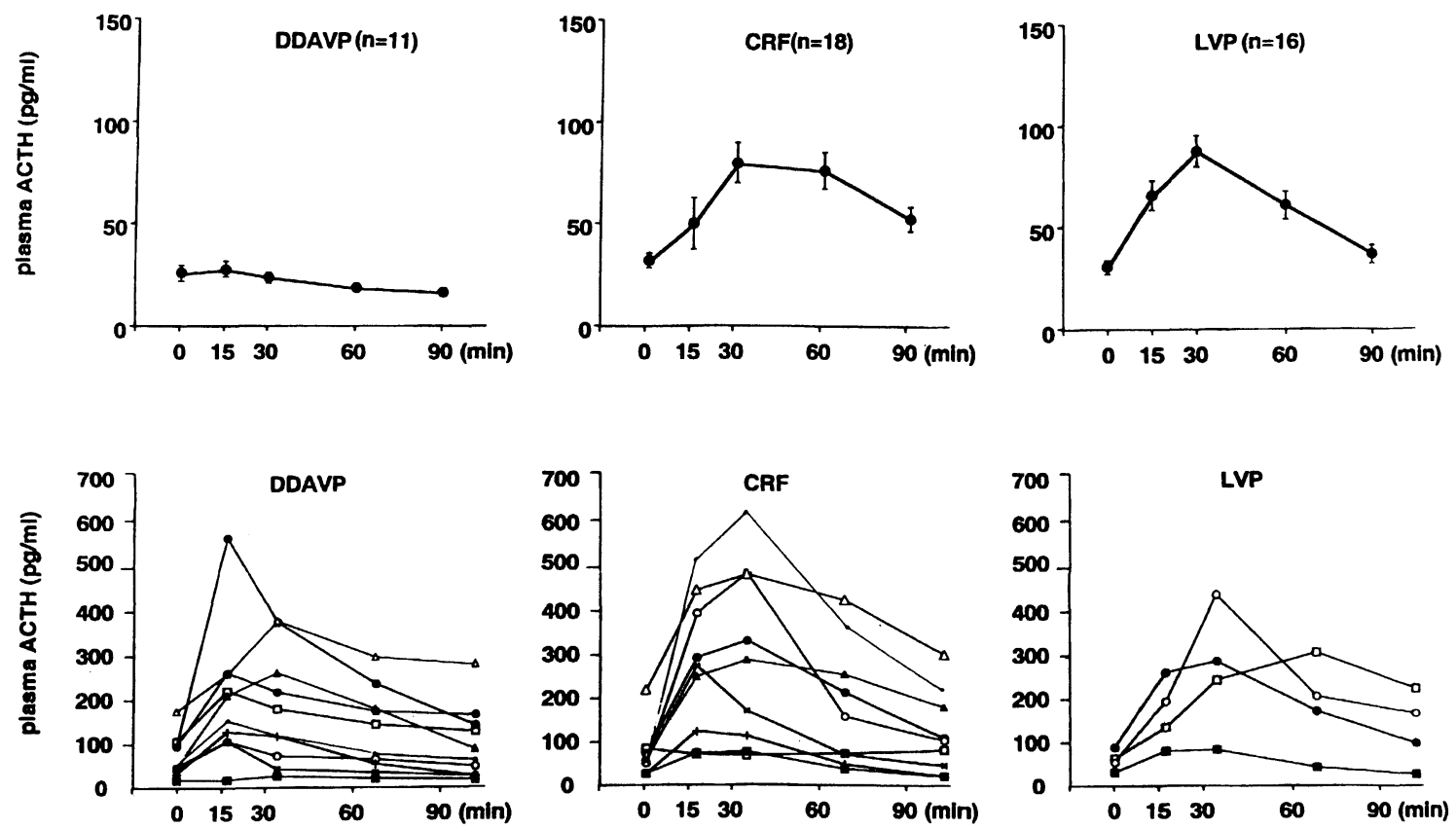

Fig. 2. Comparison of responses to CRH, LVP and DDAVP in normal subjects (upper) and patients with Cushing's disease (lower). Five $\mu \mathrm{g}$ of DDAVP (left) or $100 \mu \mathrm{g}$ of hCRH (middle) was administered by an intravenous bolus injection, and 10 I.U. of LVP (right) was administered by an intramuscular injection. In normal subjects, ACTH concentrations are shown as the mean \pm SEM. The same symbol in the 3 lower panels indicates the same individual.

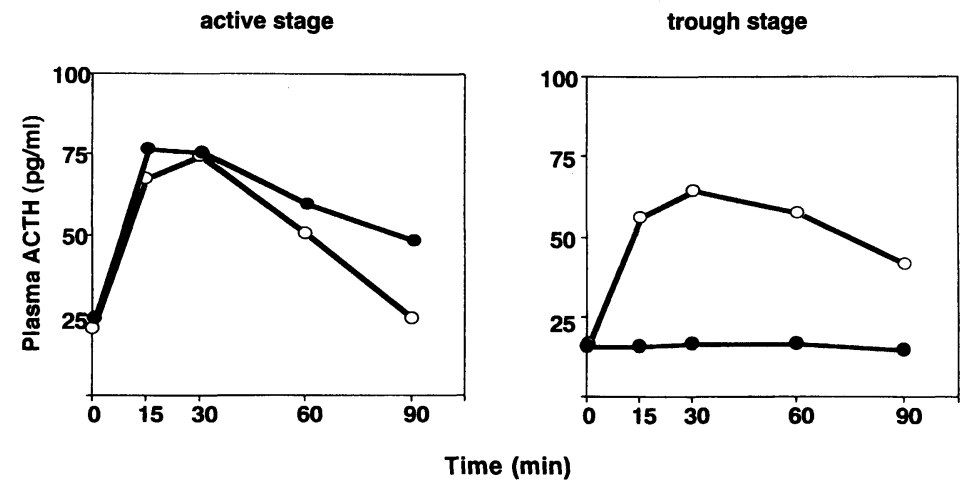

Fig. 3. Comparison of responses to DDAVP and CRH in a patient with Cushing's disease exhibiting periodicity. A hundred $\mu \mathrm{g}$ of hCRH (open circles) or $5 \mu \mathrm{g}$ of DDAVP (solid circles) was administered by an intravenous bolus injection in active (left) or trough (right) stage.

response of the plasma $\mathrm{ACTH}$ level implies that DDAVP directly stimulates ACTH release from pituitary adenomas. The peak levels of plasma ACTH of all the individuals with Cushing's disease exceeded $200 \%$ of the basal levels (Fig. 1), while the plasma ACTH levels remained less than $150 \%$ of the basal levels in all other groups. Malerbi et al. [15] demonstrated that measurement of plasma cortisol after 10 of $5 \mu \mathrm{g}$ of DDAVP administration may be useful in the differential diagnosis of Cushing's syndrome. Our results, however, demonstrated that measurement of plasma ACTH after injection of $5 \mu \mathrm{g}$ DDAVP provides both higher sensitivity and higher specificity in the diagnosis of Cushing's disease (Table 1). In addition, a $5 \mu \mathrm{g}$ injection of DDAVP could cause less side effects 
Table 2. ACTH concentrations in incubation media and total CAMP accumulations in incubation media and cytoplasm after incubation with $10 \mathrm{nmol} / \mathrm{L}$ of CRH, $100 \mathrm{nmol} / \mathrm{L}$ of DDAVP, or $100 \mathrm{nmol} / \mathrm{L}$ of AVP

\begin{tabular}{|c|c|c|c|c|}
\hline & Case & 1 & 2 & 3 \\
\hline ACTH & control & $55 \pm 7.2$ & $25 \pm 3.8$ & $17 \pm 2.5$ \\
\hline concentration & $\mathrm{CRH}^{\mathrm{a})}$ & $106 \pm 10.2$ & $60 \pm 5.5$ & $80 \pm 6.5$ \\
\hline \multirow[t]{2}{*}{$(\mathrm{nmol} / \mathrm{L} / 3 \mathrm{~h})$} & DDAVPb) & $98 \pm 8.1$ & $47 \pm 3.2$ & $62 \pm 4.4$ \\
\hline & $\left.A V P^{c}\right)$ & $101 \pm 6.7$ & $43 \pm 3.2$ & $83 \pm 6.4$ \\
\hline cAMP & control & $6.5 \pm 1.1$ & $2.6 \pm 0.6$ & \\
\hline accumulation & $\mathrm{CRH}^{\mathrm{a})}$ & $15.0 \pm 2.3$ & $5.8 \pm 1.0$ & \\
\hline \multirow[t]{2}{*}{$(\mathrm{nmol} / \mathrm{L} / 15 \mathrm{~min})$} & DDAVPb) & $5.8 \pm 0.8$ & $3.0 \pm 0.3$ & \\
\hline & $\left.A V P^{c}\right)$ & $6.0 \pm 0.6$ & $3.1 \pm 0.2$ & \\
\hline
\end{tabular}

ACTH concentrations and cAMP accumulations were determined by RIA after the incubation with CRH, DDAVP, or AVP. ${ }^{\text {a) Treatment with }}$ $10 \mathrm{nmol} / \mathrm{L}$ of CRH. ${ }^{\text {b) }}$ Treatment with $100 \mathrm{nmol} / \mathrm{L}$ of DDAVP. ${ }^{\mathrm{c}}$ Treatment with $100 \mathrm{nmol} / \mathrm{L}$ of AVP. Values are the mean \pm SEM $(n=3)$.

$\mathbf{K b}$
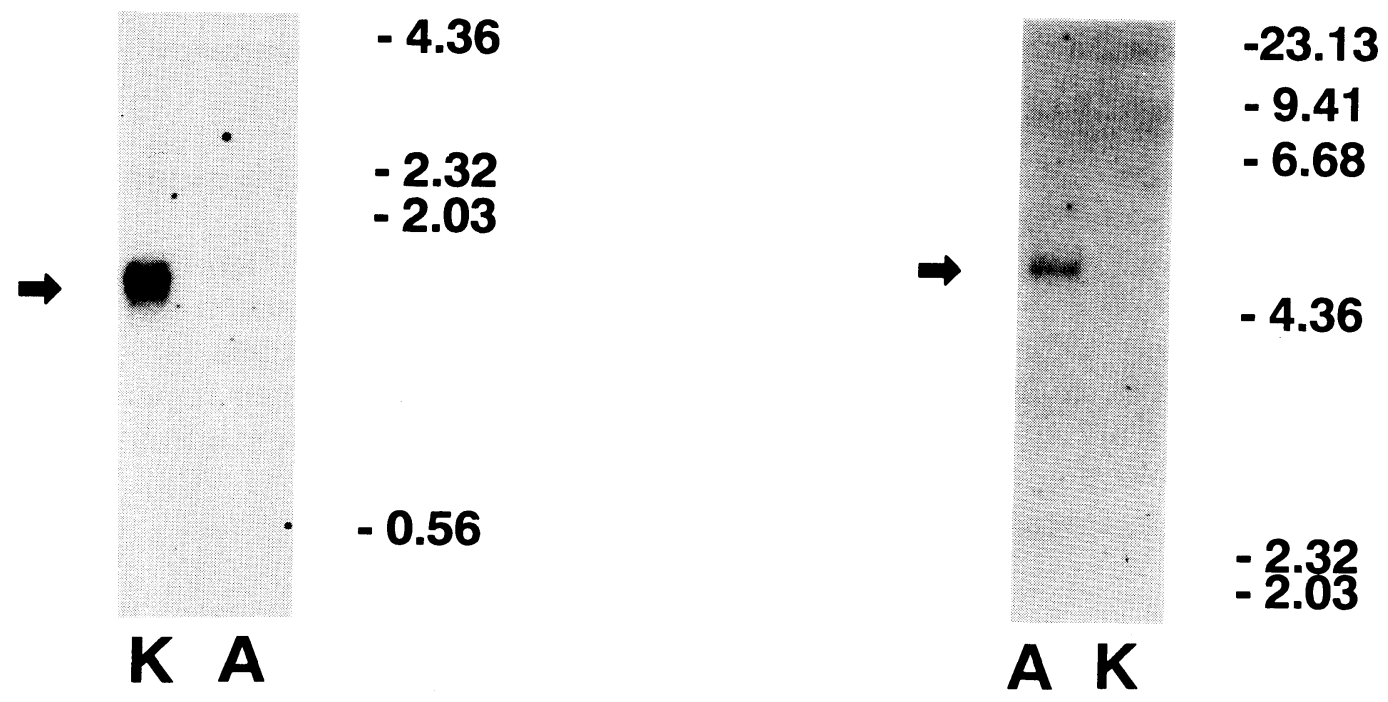

Fig. 4. Detection of V2 and V1b vasopressin receptor mRNAs by Northern blot hybridization. Total RNA extracted from corticotropic adenoma and normal human kidney tissue was loaded on lanes A and $K$, respectively. The blotted membrane was hybridized with a probe for V2 receptor (left), then stripped and rehybridized with one for V1b (right). Arrows indicate positions of $1.8 \mathrm{~kb} \mathrm{~V} 2$ receptor mRNA and $4.8 \mathrm{~kb}$ V1b receptor mRNA.

than a $10 \mu \mathrm{g}$ injection. Indeed, no severe side effects were observed in the present study.

It is uncertain why DDAVP stimulates ACTH release only in patients with Cushing's disease. We tested the possibility of aberrant expression of V2 receptor on corticotropic adenoma cells and ruled it out by demonstrating no response of cAMP to DDAVP (Table 2) and no presence of V2 receptor mRNA in these cells (Fig. 4). Alternatively, DDAVP functions though V1b receptors on the 
corticotropic adenoma cells which indeed expressed V1b receptor mRNA (Fig. 4). Then we examined whether $\mathrm{V} 1 \mathrm{~b}$ receptors on corticotropic adenoma cells showed higher sensitivity than those on normal corticotrophs to all vasopressin agonists including AVP, LVP and DDAVP. In normal subjects, plasma ACTH responses to LVP were of almost the same degree as those to CRH. In patients with Cushing's disease, however, plasma ACTH responses to LVP were less sharp than those to $\mathrm{CRH}$ (Fig. 2). On the other hand, plasma ACTH responded to DDAVP administration only in the patients with Cushing's disease. These findings indicate that $\mathrm{V} 1 \mathrm{~b}$ receptor on corticotropic adenoma cells may show higher sensitivity only to DDAVP, although dose-related effects of LVP in the two groups have not yet been compared. If the $\mathrm{V} 1 \mathrm{~b}$ receptor shows higher sensitivity to all vasopressin agonists, there may be some changes in the receptor itself or post-receptor pathways in corticotopic adenoma cells. But, since the receptor showed higher sensitivity only to DDAVP in the present study, some changes in the receptor itself, especially in the extracellular domain, are likely to be present. In the normal human pituitary [14] and corticotroph adenomas [21], the nucleotide sequences of the $\mathrm{V} 1 \mathrm{~b}$ receptors are identical. This may indicate the alternative possibility of some changes in the sugar chain of $\mathrm{V} 1 \mathrm{~b}$ receptors on corticotropic adenoma cells.

We experienced a case of Cushing's disease in which plasma ACTH levels exhibited cyclic change and responded to DDAVP injection only in the active stage of the disease (Fig. 3 ). This indicates that the DDAVP test is useful for judging the activity of Cushing's disease.

Ectopic production of ACTH from nonpituitary tumors has been reported in $10-15 \%$ of patients with Cushing's syndrome, and ACTH-producing bronchial carcinoid tumor is the most common cause of ectopic ACTH syndrome. ACTHproducing bronchial carcinoid tumors are generally small, and the clinical presentation and hormonal profile are often misleading and can mimic Cushing's disease. In this study, plasma ACTH levels in response to DDAVP showed no increase in patients with ectopic ACTH syndrome. This finding suggests that the DDAVP test is a helpful tool for differentiating Cushing's disease from ectopic ACTH syndrome, although the number of patients studied was small. Recently, some studies [22] have indicated the possibility of plasma ACTH response to DDAVP in patients with ectopic ACTH syndrome, so further studies should be conducted.

In conclusion, our findings strongly suggest that the DDAVP test is a safe and valuable tool for the diagnosis of ACTH-dependent Cushing's syndrome, especially for the discrimination of Cushing's disease from normality.

\section{Acknowledgments}

We wish to thank Ms. I. Dobashi for her technical assistance, an Dr. Y. Iwasaki for the generous gift of a human V2 receptor clone.

This study was supported in part by a research grant from the Japanese Ministry of Education, Science and Culture.

\section{References}

1. Malchoff CD, Rosal J, Debold CR (1989) Adrenocorticotropin-independent bilateral macronodular adrenal hyperplasia: An unusual cause of Cushing's syndrome. J Clin Endocrinol Metab 34: 852-859.

2. Aiba M, Hirayama A, Iri H (1990) Primary adrenal micronodular dysplasia: Enzyme histochemical and ultrastructural studies of two cases with a review of the literature. Hum Pathol 21: 503-511.

3. Horiba $N$, Suda T, Aiba $M$, Naruse $M$, Nomura $K$, Imamura M, Demura H (1995) Lysine vasopressin stimulation of cortisol secretion in patients with adrenocorticotropin-independent macronodular hyperplasia. J Clin Endocrinol Metab 80: 2336-2341.

4. Nugent CA, Nichols T, Tyler FH (1965) Diagnosis of Cushing's syndrome, single dose dexamethasone suppression test. Arch Intern Med 116: 172-176.

5. Orth DN (1992) Corticotropin-releasing hormone in humans. Endocr Rev 13: 164-191.

6. Hermus AR, Pieters GF, Pesman GJ, Smals AG, Benraad TJ, Kloppenborg PW (1986) The corticotropin-releasing hormone test versus the high-dose dexamethasone test in the differential diagnosis of Cushing's syndrome. Lancet 2: 540- 
544.

7. Suda T, Tozawa F, Dobashi I, Horiba N, Ohmori N, Yamakado M, Yamada M, Demura H (1993) Corticotropin-releasing hormone, proopiomelanocortin, and glucocorticoid receptor gene expression in adrenocorticotropin-producing tumors in vitro. $J$ Clin Invest 92: 2790-2795.

8. Oldfield EH, Doppman JL, Nieman LK, Chrousos GP, Miller DL, Katz DA, Cutler GB, Loriaux DL (1991) Petrosal sinus sampling with and without corticotropin-releasing hormne for the differential diagnosis of Cushing's syndrome. New Eng J Med 325: 897-905.

9. Philipponneau M,Nocaudie M, Epelbaum J, De Keyzer Y, Lalau JD, Marchandise X, Bertagna X (1994) Somatostatin analogs for the localization and preoperative treatment of an adrenocorticotropinsecreting bronchial carcinoid tumor. J Clin Enadocrinol Metab 78: 20-24.

10. Raymond V, Leung P, Veilleux R, Labrie F (1985) Vasopressin rapidly stimulates phosphatidic acidphosphatidylinositol turnover in rat anterior pituitary cells. FEBS Lett 1182: 1196-2000.

11. Antoni FA (1984) Novel ligand specificity of pituitary vasopressin receptors in the rat. Neuroendocrinology 39: 186-188.

12. Morel A, O'Caroll A-M, Brownstein MJ, Lolait SJ (1992) Molecular cloning and expression of a rat V1a arginine vasopressin receptor. Nature (Lond) 356: 523-526.

13. Birnbaumer $M$, Seibold A, Gilbert S, Ishido $M$, Barberis C, Antaramian A, Brabet P, Rosenthal W (1992) Molecular cloning of the receptor for human antidiuretic hormone. Nature (Lond) 357: 333-335.

14. Sugimoto T, Saito M, Mochizuki S, Watanabe $Y$, Hashimoto S, Kawashima H (1994) Molecular cloning and functional expression of a cDNA encoding the human $\mathrm{V} 1 \mathrm{~b}$ vasopressin receptor. J Biol Chem 269: 27088-27092.

15. Malerbi DA, Mendonca BB, Liberman B, Toledo SPA, Corradini MCM, Cunha-Neto MB, Fragoso MCBV, Wajchenberg BL (1993) The desmopressin stimulation test in the differencial diagnosis of Cushing's syndrome. Clin Endocrinol 38: 463-472.

16. Sawyer WH, Acosta M, Ballaspiri L, Judd J, Manning M (1974) Structural changes in the arginine vasopressin molecule that enhance antidiuretic activity and specificity. Endocrinology 94: 1106-1115.

17. Nomura $K$, Ohmura K, Nakamura $Y$, Horiba N, Shirakura Y, Sato Y, Ujihara M, Ohki K, Shizume K (1989) Porcine luteinizing hormone isoform(s): Relationship between their molecular structures, and renotropic versus gonadotropic activities. Endocrinology 124: 712-719.

18. Suda T, Tozawa F, Ushiyama T, Sumitomo T, Yamada M, Demura H (1990) Interleukin-1 stimulates corticotropin-releasing factor gene expression in rat hypothalamus. Endocrinology 126: 1223-1228.

19. Suda T, Liotta AS, Krieger DH (1978) $\beta$-endorphin is not detectable in plasma from normal human subjects. Science 202: 221-223.

20. Suda T (1992) Corticotropin-releasing factor gene expression. Methods in Neuroscience 9: 23-31.

21. de Keyzer Y, Auzan C, Lenne F, Beldjord C, Thibonnier M, Bertagna X, Clauser E (1994) Cloning and functional expression of the human $\mathrm{V} 3$ pituitary vasopressin receptor. FEBS Lett 356: 215-220.

22. Newell-Price J, Perry L, Medbak S, Monson J, Savage M, Besser M, Grossman A (1997) A combined test using desmopressin and corticotropin-releasing hormone in the differential diagnosis of Cushing's syndrome. J Clin Endocrinol Metab 82: 176-181. 